\title{
Mapping of medical schools: the distribution of undergraduate courses and annual vacancies in Brazilian cities in $\mathbf{2 0 2 0}$
}

Cartografia das escolas médicas: a distribuição de cursos e vagas nos municípios brasileiros em 2020

\author{
Douglas Vinícius Reis Pereira' (10 | douglas.vinicius.bh@outlook.com \\ Daniel de Lima Ruas Fernandes' 1 (1) danlimaruas@gmail.com \\ Julia Ferreira Mari' 1 (1) juliafmario5@gmail.com \\ Ana Luiza de Faria Lage' 1 (1) anafaria96@outlook.com \\ Ana Paula Pinheiro Chagas Fernandes' 1 | $\mid$ anapaulapcf@gmail.com
}

\begin{abstract}
Introduction: The number of medical schools in Brazil, as well as the number of vacancies offered at these schools, has grown considerably in the last few years. Since 2013, this increase has aimed at reaching especially the rural and underserved areas of the country.

Objective: Considering that there are many different interests concerning this debate and that this reality directly influences the education and health policies of the country, the aim of this study was to evaluate the number and the distribution of the medical courses, as well as vacancies in these schools in 2020, presenting an updated overview of the Brazilian medical schools.

Methods: This was a cross-sectional study, based on data gathered from the Brazilian Ministry of Education and Institute of Geography and Statistics (IBGE) website. The utilized variables were the number of courses, number of vacancies offered in each course, characteristics of the cities where the medical schools are located, such as population size, Human Development Index (HDI) and distance to the capital city of each state.

Results: Among the institutions that have already initiated their activities, there are 328 active courses, offering 35.480 vacancies for Medical School applicants. There is a difference when analyzing public or private institutions and paid or tuition-free institutions. There is a greater offer of paid courses $(74,1 \%)$ and of courses located in the countryside $(69,8 \%)$. Among the courses in the countryside, $27,8 \%$ of the vacancies are offered within $100 \mathrm{~km}$ of the capital city. Only 7,9\% of the annual vacancies are offered in cities with a medium HDI, and the remainder are offered in cities with high or very high HDI. The increase in $\mathrm{HDI}$ is related to the higher proportion of private courses offering medical vacancies. It was observed that there is no correspondence between the absolute number of vacancies and the population of the North region, different from what occurs in the other regions of the country.

Conclusions: Medical training is under many influences, such as economic and political trends. This discussion needs to consider the regionalization and democratization of access. It was observed that public institutions tend to be located in municipalities that are farther away from the capitals. Even though there is now greater homogeneity between the regions, the Southeast still concentrates almost half of the vacancies in medical courses. Also, the increase in the number of vacancies in private courses brings up the reflection about the socioeconomic profile of medical students who have the opportunity to gain access to this level of education.
\end{abstract}

Keywords: Medical Education; Medical Schools; College Education; Health Policies; Medical Students.

\section{RESUMO}

Introdução: O número de cursos de Medicina no Brasil e a quantidade de vagas ofertadas cresceram consideravelmente nos últimos anos. A partir de 2013, essa expansão tinha o objetivo de atingir sobretudo o interior do país.

Objetivo: Considerando que existem diversos interesses em torno dessa expansão e que essa realidade influencia diretamente as políticas de educação e saúde do país, o objetivo deste estudo foi analisar a quantidade e a distribuição, em 2020, desses cursos e vagas nos municípios brasileiros.

Método: Trata-se de estudo transversal com dados disponibilizados pelo Ministério da Educação e pelo Instituto Brasileiro de Geografia e Estatística (IBGE). As variáveis estudadas foram números de cursos, número de vagas e características dos municípios das escolas médicas, como tamanho da população, Índice de Desenvolvimento Humano (IDH) e distância em relação à capital do respectivo estado.

Resultados: Há 328 cursos em atividade que ofertam 35.480 vagas para ingressantes em Medicina. Ocorre diferença quando se analisam instituições públicas ou privadas e instituições gratuitas ou pagas. Há maior oferta de vagas em cursos pagos $(74,1 \%)$ e em municípios de interior (69,8\%). No interior, $27,8 \%$ das vagas são ofertadas por municípios distantes de um a $100 \mathrm{~km}$ da capital. A menor parte das vagas $(7,9 \%)$ é ofertada em municípios de IDH médio, sendo o restante em municípios de IDH alto ou muito alto. O aumento do IDH está relacionado à maior proporção de cursos privados ofertando vagas de Medicina. Observou-se que não há correspondência entre o número absoluto de vagas e a população da Região Norte, o que ocorre nas demais regiões do país.

Conclusões: A formação médica está sob várias influências, a exemplo das tendências econômicas e políticas. Essa discussão precisa levar em consideração a regionalização e a democratização do acesso. Observou-se tendência de as instituições públicas se destinarem a municípios mais distantes. Apesar de maior homogeneidade entre as regiões, a Região Sudeste ainda concentra quase metade das vagas. Além disso, o aumento do número de vagas em cursos privados evoca o questionamento sobre o perfil de estudantes que têm a oportunidade de acessar essa graduação.

Palavras-chave: Educação Médica; Escolas Médicas; Educação Superior; Políticas de Saúde; Estudantes de Medicina.

${ }^{1}$ Faculdade de Ciências Médicas de Minas Gerais, Belo Horizonte, Minas Gerais, Brazil.

Chief editor: Daniela Chiesa $\quad$ Associate editor: Pedro Tadao Hamamoto Filho

Received on 07/28/20; Accepted on 11/06/20. | Evaluated by double blind review process. 


\section{INTRODUCTION}

The current distribution of medical schools in Brazil reflects the relatively recent public policies aimed at improving national health indicators ${ }^{1}$. Especially in the 2010s, the deficit of professionals increased due to the greater offer of public health services ${ }^{2}$.

The increase in the number of medical courses is a process that has been observed in other periods in the country's history ${ }^{3}$. The 1960s were characterized by the creation of 35 medical schools. This increase progressed to the point that 113 schools were created at the end of the last century 4 . However, this expansion was more intense in the first decades of the new century, since, in the last 20 years, the number of schools almost tripled $^{5}$. At the end of 2010, there were 179 medical courses ${ }^{5}$, reaching a total of 351 medical courses and 37,221 authorized vacancies in 2020.

This process is closely related to the enactment of Law n. 12,871/2013, which implemented the Mais Médicos Program (PMM, Programa Mais Médicos), in an attempt to decrease the inequality of access to health services by the population ${ }^{6}$. This difference results from the concentration of doctors and medical schools in the most developed urban centers, resulting in a shortage of these professionals in regions with worse health indicators, which are generally more distant from large centers'.

In 2012, according to primary registrations by the Federal Council of Medicine (CFM, Conselho Federal de Medicina), the Ministry of Health (MS) announced a national average of 1.8 doctors per 1,000 inhabitants in Brazil. This number is lower than the average of other countries such as Portugal, the United Kingdom, Uruguay and Argentina, which had, in the same year, a ratio of $3.8 ; 2.7 ; 3.7$ and 3.9 doctors per 1,000 inhabitants, respectively ${ }^{1}$. Although it is a national average, it is important to note that the geographical distribution of these professionals is unequal. This is because in 2013 , only $8 \%$ of doctors worked in municipalities with less than 50,000 inhabitants, which represent $90 \%$ of the country's cities ${ }^{2}$. Aiming to attenuate this disparity, the PMM planned a targeted expansion of vacancies in undergraduate and medical residency courses. This expansion should follow the criteria of social need, decentralization and the shift towards the countryside location of medical schools ${ }^{1-3}$.

However, the increase in the number of medical courses has resulted in an intensive debate, involving government actors, federal, state and municipal public managers, supplementary health managers, medical entities, medical education specialists and entities, students and student movement entities, with divergent opinions. This whole debate is justified by the perception that the increase in the number of doctors must necessarily be linked to the improvement of training, specialization and permanent education of these professionals, since good training is directly related to the quality of health care offered to the population ${ }^{7}$.

Therefore, this study aims to analyze the number, geographic distribution and characteristics of the municipalities that host medical courses. Thus, an overview is presented in relation to Brazilian medical schools in 2020, aiming to contribute to the analysis of the offer of medical training in the country.

\section{METHOD}

This is a cross-sectional study, using data from the electronic portal of the Brazilian Ministry of Education (e-MEC) ${ }^{8}$ and from the Brazilian Institute of Geography and Statistics (IBGE) ${ }^{9}$. The work was registered at the Brazil Platform/National Ethics Commission in Research and approved by the Research Ethics Committee of Faculdade de Ciências Médicas de Minas Gerais.

Regarding the schools, the following variables were collected: administrative link, whether it is a tuition-free institution and the number of new vacancies that are offered annually. In relation to the municipalities, the variables: geographic region, whether it is located in the capital city or in the countryside, distance to the state capital, size and Human Development Index (HDI).

As for the administrative link, the schools were classified as public - municipal, state or federal, and private- for-profit and nonprofit schools. The municipalities were classified according to the geographic region: North, Northeast, Midwest, Southeast and South.

Population data for each of the regions ${ }^{12}$ were also obtained, aiming to obtain the ratio between vacancies and the number of inhabitants. Therefore, it was possible to update the historical association presented by the Ministry of Health (MS) about the number of vacancies per number of inhabitants in the Brazilian regions'.

The distance to the capital city was stratified in intervals of 1-100 km, 101-200 km, 201-300 km, 301-400 km, 401-500 $\mathrm{km}$ and $501-900 \mathrm{~km}$. The size of the municipality was classified based on the number of inhabitants, subdivided into Small (less than 20,000 inhabitants), Medium-small (20,000-50,000 inhabitants), Medium (50,000-100,000 inhabitants), Mediumlarge (100,000-500,000 inhabitants) and Large (more than 500,000 inhabitants), as proposed by the book "Subsidies for the planning of social policies"10. The United Nations (UN) ${ }^{11}$ proposal was used for the HDI classification, which divides the values between low (below 0.550), medium (0.550-0.699), high (0.700-0.799) and very high (above 0.800).

The inclusion criterion for this study was the existence of a medical course on the e-MEC portal, regardless of the medical school's education system, with the variables updated in February 2020. Courses that were extinct or that had not yet 
started their activities were excluded.

Data analysis, performed using software $\mathrm{R}$, version 3.4.0, was descriptive, using absolute and relative frequencies for categorical variables and mean and standard deviation or median and $25^{\text {th }}$ and $75^{\text {th }}$ percentiles for continuous variables.

\section{RESULTS}

In February 2020, there were 351 medical courses in Brazil, totaling 37,221 authorized vacancies. Of these, 21 had not yet started their activities, representing 1,511 vacancies. One course was extinct, and one was being extinct, totaling 230 vacancies that ceased to exist. Therefore, this study included 328 active courses that had initiated their activities, totaling 35,480 vacancies for those students entering medical courses in Brazil.

Table 1 shows the distribution of courses and vacancies in medical schools based on the administrative link of the institution, whether public (municipal, state or federal) or private (for-profit or nonprofit); geographic region; and characteristics of the municipalities (distance from the state capital, size and $\mathrm{HDI}$ ).

There is a predominance of courses and vacancies in private institutions. The difference is greater when comparing paid versus tuition-free institutions: almost three quarters of new medical vacancies are offered in paid courses.

Among the public institutions, there are more courses and vacancies in federal institutions, followed by state and municipal institutions. Moreover, all municipal public institutions are paid. Regarding the private institutions, there is a slight predominance of medical courses and vacancies in nonprofit institutions.

There is a greater concentration of courses and vacancies in the Southeast region, followed by the Northeast, South, Midwest and North regions, respectively. There is a predominance of medical courses and vacancies in the municipalities that are closer to the capital city, with most of them located within $100 \mathrm{~km}$ from the capital. There are fewer courses and vacancies in municipalities located over $500 \mathrm{~km}$ from the capital, and the maximum distance found was $900 \mathrm{~km}$.

Large municipalities concentrate the largest number of vacancies, followed by medium-large ones. There is only one medical course located in a small municipality, which offers 120 vacancies, so it was included together with schools located in medium-small municipalities.

There are no medical schools in municipalities with low $\mathrm{HDI}$. There is a greater number of courses and vacancies in municipalities with high $\mathrm{HDI}$, followed by municipalities with very high $\mathrm{HDI}$ and those with medium HDI.
Table 1. Distribution of medical courses and vacancies available by administrative link, geographic region and characteristics of the municipalities, Brazil, 2020.

\begin{tabular}{|c|c|c|}
\hline & $\begin{array}{c}\text { Total courses } \\
\text { n (\%) }\end{array}$ & $\begin{array}{c}\text { Total vacancies } \\
\text { n (\%) }\end{array}$ \\
\hline \multicolumn{3}{|l|}{ Administration } \\
\hline Public & $128(39.0)$ & $10,934(30.8)$ \\
\hline Private & $200(61.0)$ & $24,546(69.2)$ \\
\hline \multicolumn{3}{|l|}{ Type of institution } \\
\hline Municipal public & $18(5.5)$ & $1,744(4.9)$ \\
\hline State public & $33(10.1)$ & $2,198(6.2)$ \\
\hline Federal Public & $77(23.5)$ & $6,992(19.7)$ \\
\hline Private nonprofit & $109(33.2)$ & $13,510(38.1)$ \\
\hline Private for-profit & $91(27.7)$ & $11,036(31.1)$ \\
\hline \multicolumn{3}{|l|}{ Tuition } \\
\hline Tuition-free & $110(33.5)$ & $9,190(25.9)$ \\
\hline Paid & $218(66.5)$ & $26,290(74.1)$ \\
\hline \multicolumn{3}{|l|}{ Region } \\
\hline North & $25(7.6)$ & $2,515(7.1)$ \\
\hline Northeast & $79(24.1)$ & $8,496(23.9)$ \\
\hline Midwest & $30(9.1)$ & $2,957(8.3)$ \\
\hline Southeast & $139(42.4)$ & $16,412(46.3)$ \\
\hline South & $55(16.8)$ & $5,100(14.4)$ \\
\hline \multicolumn{3}{|l|}{ Type of municipality } \\
\hline Capital city & $99(30.2)$ & $14,087(39.7)$ \\
\hline Countryside & $229(69.8)$ & $21,393(60.3)$ \\
\hline \multicolumn{3}{|l|}{$\begin{array}{l}\text { Distance from the } \\
\text { capital (km) }\end{array}$} \\
\hline $1 \mathrm{~km}-100 \mathrm{~km}$ & $49(21.4)$ & $5,942(27.8)$ \\
\hline $101 \mathrm{~km}-200 \mathrm{~km}$ & $37(16.2)$ & $3,400(15.9)$ \\
\hline $201 \mathrm{~km}-300 \mathrm{~km}$ & $38(16.6)$ & $3,286(15.4)$ \\
\hline $301 \mathrm{~km}-400 \mathrm{~km}$ & $37(16.2)$ & $2,878(13.5)$ \\
\hline $401 \mathrm{~km}-500 \mathrm{~km}$ & $36(15.7)$ & $3,337(15.6)$ \\
\hline $501 \mathrm{~km}-900 \mathrm{~km}$ & $32(13.9)$ & $2,550(11.9)$ \\
\hline \multicolumn{3}{|l|}{ Size of the municipality } \\
\hline Small and Medium Small & $9(2.7)$ & $881(2.4)$ \\
\hline Medium & $44(13.4)$ & $3,434(9.7)$ \\
\hline Medium large & $155(47.3)$ & 14,076 (39.7) \\
\hline Large & $120(36.6)$ & $17,089(48.2)$ \\
\hline \multicolumn{3}{|l|}{ Municipal HDI } \\
\hline Medium & $41(12.5)$ & $2,810(7.9)$ \\
\hline High & $221(67.4)$ & $23,321(65.7)$ \\
\hline Very high & $66(20.1)$ & $9,349(26.4)$ \\
\hline
\end{tabular}


Figure 1 shows the distribution of medical schools in the Brazilian territory, highlighting them according to their location in the capital or in the countryside. The representation is proportional to the number of medical schools in that city.

It is observed that Brazilian medical schools are not well distributed across the country. It can be seen that the Southeast and South regions have a large concentration of schools, although the latter apparently has a more homogeneous distribution in its territory. The city capital of São Paulo, for instance, has the largest number of schools in the same city, totaling twelve schools. In Minas Gerais, on the other hand, there is a remarkable contrast in relation to the concentration of medical schools: the south of the state, with many schools, is similar to São Paulo, and the north of the state, with a lower number of schools, is similar to the countryside of the state of Bahia. In the Northeast region, the concentration of schools in the capitals and coastal regions stands out; there are exceptions, which have a greater number of schools in the countryside, such as the state of Bahia and those with a lower number of schools, such as the states of Paraíba and Piauí. In the North and Midwest regions it is possible to observe a concentration of schools in the capitals, with isolated schools in the countryside. Of the states in these regions, Goiás stands out with a larger number of schools in the countryside.

Table 2 shows the comparison between public or private, and tuition-free or paid medical schools, showing the distribution of both courses and vacancies at these institutions.

Most of the institutions that offer medical courses in the North region are private. A public medical course with municipal administration charges a monthly fee (tuition) in this Brazilian region.

In the Northeast region, there is a greater number of courses in public institutions than in private ones; however, the number of vacancies in public institutions is lower than those in private ones. In this region there are no public courses that charge tuition.

There is a predominance of courses and vacancies in public institutions in the Midwest region. This is not observed when using the tuition-free or paid classification, since there are municipal public courses that charge tuition. The tuition-free courses concentrate less than one-third of medical vacancies in this region.

There is a predominance of courses in private institutions In the southeast region, also showing a predominance of the number of vacancies in these schools. The difference is greater when analyzing tuition-free or paid institutions, and this is the region with the highest concentration of vacancies in paid medical courses.

Private institutions also predominate In the south region. The difference is slightly greater when comparing tuition-free or paid courses, since a municipal public institution charges tuition in that region.

Figure 1. Distribution of medical schools by city, in number of schools, and in capitals and the countryside, Brazil, 2020.

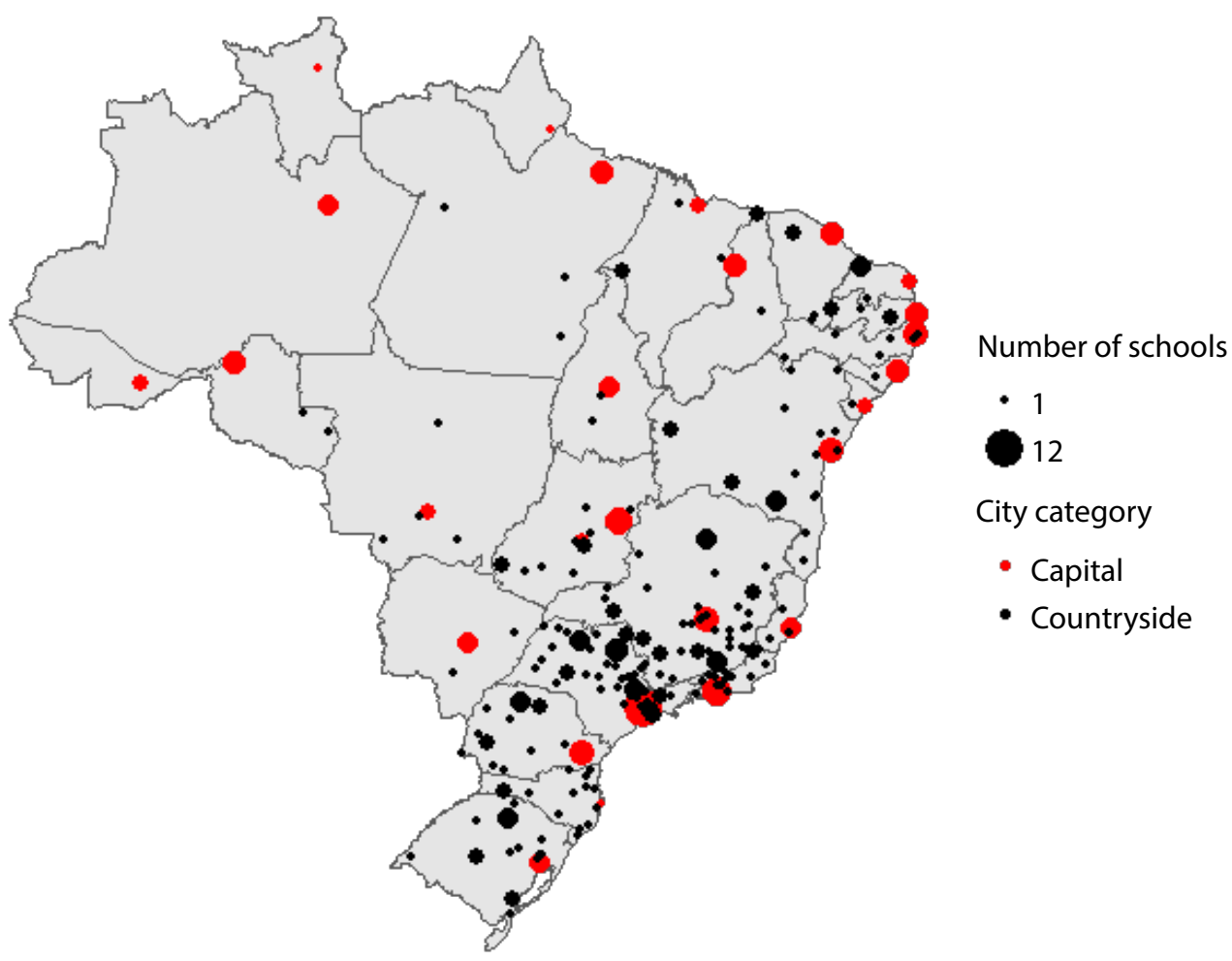


Table 2. Comparison of the distribution of courses and vacancies in public and private institutions, tuition-free and paid, Brazil, 2020, percentages by lines.

\begin{tabular}{|c|c|c|c|c|c|c|c|c|}
\hline & \multicolumn{2}{|c|}{ Public Institutions } & \multicolumn{2}{|c|}{ Private Institutions } & \multicolumn{2}{|c|}{ Tuition-Free Institutions } & \multicolumn{2}{|c|}{ Paid Institutions } \\
\hline & $\begin{array}{c}\text { Total } n \text {. of } \\
\text { courses } \\
\text { n (\%) }\end{array}$ & $\begin{array}{c}\text { Total } \mathbf{n} \text {. of } \\
\text { vacancies } \\
\mathbf{n}(\%)\end{array}$ & $\begin{array}{c}\text { Total } n . \text { of } \\
\text { courses } \\
\text { n (\%) }\end{array}$ & $\begin{array}{c}\text { Total } \mathbf{n} \text {. of } \\
\text { vacancies } \\
\mathbf{n}(\%)\end{array}$ & $\begin{array}{c}\text { Total } \mathbf{n} \text {. of } \\
\text { courses } \\
\text { n (\%) }\end{array}$ & $\begin{array}{c}\text { Total } \mathbf{n} \text {. of } \\
\text { vacancies } \\
\text { n (\%) }\end{array}$ & $\begin{array}{c}\text { Total } n . \text { of } \\
\text { courses } \\
n(\%)\end{array}$ & $\begin{array}{c}\text { Total } \mathbf{n . ~ o f} \\
\text { vacancies } \\
\mathbf{n}(\%)\end{array}$ \\
\hline \multicolumn{9}{|l|}{ Region } \\
\hline North & $11(44.0)$ & $992(39.4)$ & $14(56.0)$ & $1.523(60.6)$ & $10(40.0)$ & $872(34.7)$ & $15(60.0)$ & $1,643(65.3)$ \\
\hline Northeast & $41(51.9)$ & $3,071(36.1)$ & $38(48.1)$ & $5,425(63.9)$ & $41(51.9)$ & $3,071(36.1)$ & $38(48.1)$ & $5,425(63.9)$ \\
\hline Midwest & $19(63.3)$ & $1,592(53.8)$ & $11(36.7)$ & $1,365(46.2)$ & $12(40.0)$ & $834(28.2)$ & $18(60.0)$ & $2,123(71.8)$ \\
\hline Southeast & $38(27.3)$ & $3,761(22.9)$ & $101(72.7)$ & $12,651(77.1)$ & $29(20.9)$ & $2,975(18.1)$ & $110(79.1)$ & $13,437(81.9)$ \\
\hline South & $19(34.5)$ & $1,518(29.8)$ & $36(65.5)$ & $3,582(70.2)$ & $18(32.7)$ & $1,438(28.2)$ & $37(67.3)$ & $3,662(71.8)$ \\
\hline \multicolumn{9}{|l|}{ Type of municipality } \\
\hline Capital & $41(41.4)$ & $4,586(32.6)$ & $58(58.6)$ & $9,501(67.4)$ & $40(40.4)$ & $4,466(31.7)$ & $59(59.6)$ & $9,621(68.3)$ \\
\hline Countryside & $87(38.0)$ & $6,348(29.7)$ & $142(62.0)$ & $15,045(70.3)$ & $70(30.6)$ & $4,724(22.1)$ & $159(69.4)$ & $16,669(77.9)$ \\
\hline \multicolumn{9}{|l|}{ Distance from capital (km) } \\
\hline $1 \mathrm{~km}-100 \mathrm{~km}$ & $9(18.4)$ & $930(15.7)$ & $40(81.6)$ & $5,012(84.3)$ & $4(8.2)$ & $430(7.2)$ & $45(91.8)$ & $5,512(92.8)$ \\
\hline $101 \mathrm{~km}-200 \mathrm{~km}$ & $14(37.8)$ & $1,082(31.8)$ & $23(62.2)$ & $2,318(68.2)$ & $9(24.3)$ & $522(15.4)$ & $28(75.7)$ & $2,878(84.6)$ \\
\hline $201 \mathrm{~km}-300 \mathrm{~km}$ & $21(55.3)$ & $1,608(48.9)$ & $17(44.7)$ & $1,678(51.1)$ & $18(47.4)$ & 1,308 (39.8) & $20(52.6)$ & $1,978(60.2)$ \\
\hline $301 \mathrm{~km}-400 \mathrm{~km}$ & $14(37.8)$ & $933(32.4)$ & $23(62.2)$ & $1,945(67.6)$ & $13(35.1)$ & $867(30.1)$ & $24(64.9)$ & $2,011(69.9)$ \\
\hline $401 \mathrm{~km}-500 \mathrm{~km}$ & $14(38.9)$ & $805(24.1)$ & $22(61.1)$ & $2,532(75.9)$ & $12(33.3)$ & $667(20.0)$ & $24(66.7)$ & $2,670(80.0)$ \\
\hline $501 \mathrm{~km}-900 \mathrm{~km}$ & $15(46.9)$ & $990(38.8)$ & $17(53.1)$ & $1,560(61.2)$ & $14(43.8)$ & $930(36.5)$ & $18(56.2)$ & $1,620(63.5)$ \\
\hline \multicolumn{9}{|l|}{ Size of the municipality } \\
\hline Small and Medium Small & $3(33.3)$ & $240(27.2)$ & $6(66.7)$ & $641(72.8)$ & $1(11.1)$ & $60(6.1)$ & $8(88.9)$ & $921(93.9)$ \\
\hline Medium & $18(40.9)$ & $1,148(33.4)$ & $26(59.1)$ & $2,286(66.6)$ & $14(31.8)$ & $770(22.4)$ & $30(68.2)$ & $2,664(77.6)$ \\
\hline Medium large & $63(40.6)$ & $4,438(31.5)$ & $92(59.4)$ & $9,638(68.5)$ & $53(34.2)$ & $3,492(24.8)$ & $102(65.8)$ & $10,584(75.2)$ \\
\hline Large & $44(36.7)$ & $5,108(29.9)$ & $76(63.3)$ & $11,981(70.1)$ & $42(35.0)$ & $4,868(28.5)$ & $78(65.0)$ & $12,221(71.5)$ \\
\hline \multicolumn{9}{|l|}{ Municipal HDI } \\
\hline Medium & $21(51.2)$ & $1,189(42.3)$ & $20(48.8)$ & $1,621(57.7)$ & $20(48.8)$ & $1,109(39.5)$ & $21(51.2)$ & $1,701(60.5)$ \\
\hline High & $86(38.9)$ & $7,363(31.6)$ & $135(61.1)$ & $15,958(68.4)$ & $74(33.5)$ & $6,139(26.3)$ & $147(66.5)$ & $17,182(73.7)$ \\
\hline Very high & $21(31.8)$ & $2,382(25.5)$ & $45(68.2)$ & 6,967 (74.5) & $16(24.2)$ & $1,942(20.8)$ & $50(75.8)$ & 7,407 (79.2) \\
\hline
\end{tabular}

There is a higher concentration of vacancies in the countryside when compared to the capital cities, regardless of the distance range in which they are located. When considering the distance range of 1 to $100 \mathrm{~km}$ from the capital, the concentration of courses and vacancies in paid schools is much higher than in any other interval.

In the range of 201 to $300 \mathrm{~km}$ away from the capital, there is a greater concentration of courses in public institutions. This does not happen in relation to the vacancies, since most of them are in private medical courses. There are three municipal public institutions that charge a monthly fee in this interval, so there is a predominance of both courses and vacancies in paid institutions.

There is a greater concentration of private and paid courses, regardless of the size of the municipality. Among the courses located in small or medium-small municipalities, the discrepancy between public/private and tuition-free/paid school is greater.

In medium-sized municipalities, there is a greater difference when comparing public/private and tuition-free/ paid institutions. When analyzing the distribution according to the HDI of the municipalities, it can be observed that the increase in the HDI is related to a higher proportion of private or paid courses.

Figure 2 shows the historical evolution of the number of vacancies in medical courses per 10,000 inhabitants in each of the five Brazilian regions. The information up to 2015 was obtained from the $\mathrm{MH}^{1}$ data and the 2020 column was updated according to the information obtained for this research.

There was a correspondence between the absolute number of vacancies and the number of inhabitants in most regions. When evaluating the regions by population size, a figure similar to that of regions with the highest number of vacancies is obtained. The North region is the exception, as it is the fourth region in the country in number of inhabitants, but the fifth in absolute number of medical vacancies. 
Figure 2. Historical evolution of the association between vacancies in medical courses and the Brazilian population, in 10,000 inhabitants.

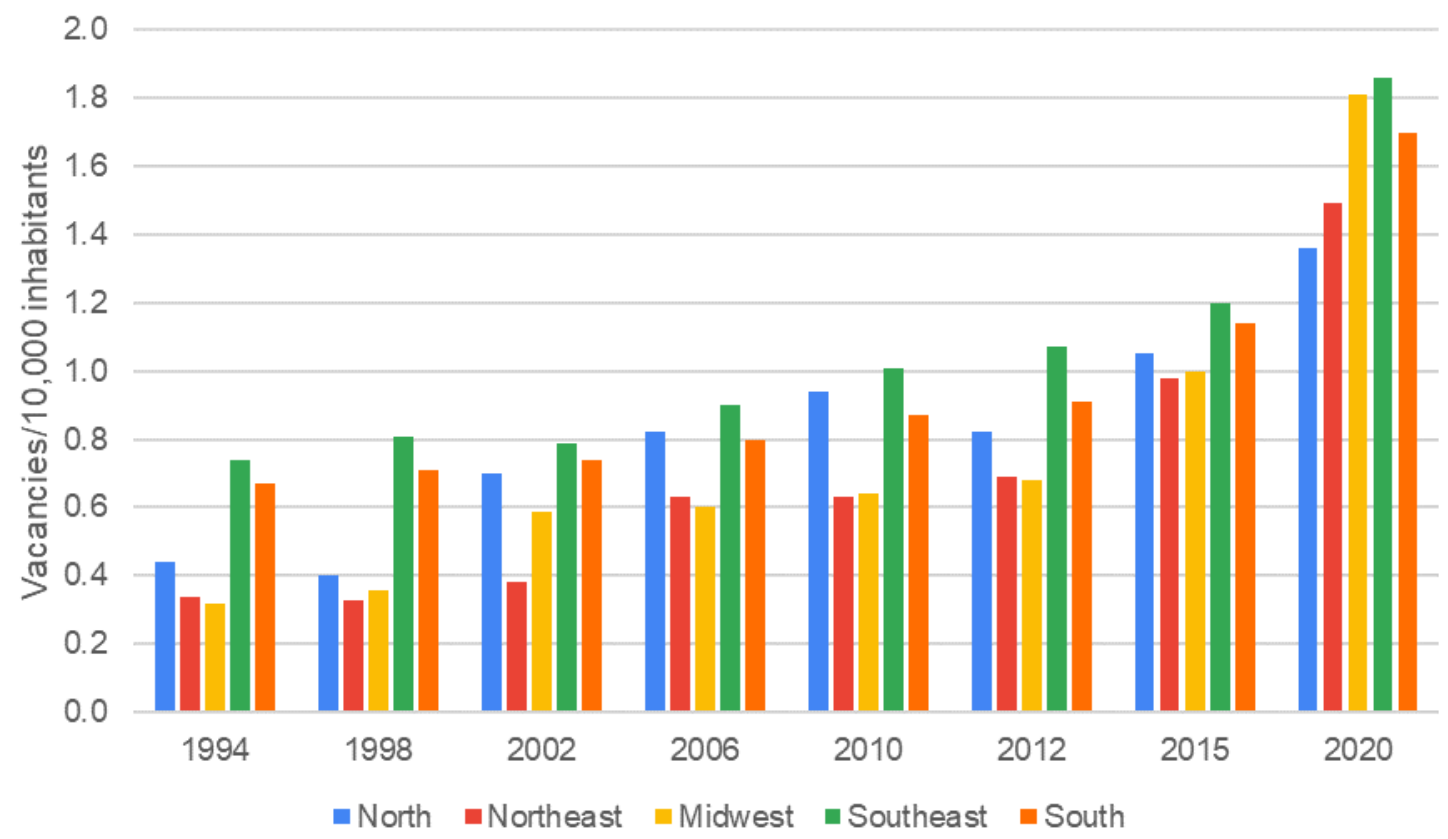

Note: Data on the ratio of vacancies in medical courses per 10,000 inhabitants in the years 1994, 1998, 2002, 2006, 2012 and 2015 were obtained from the $\mathrm{MH}^{1}$. The ratio of vacancies per 10,000 inhabitants in 2020 was obtained from data related to this research.

Figure 3. Relative density of vacancies in medical courses per 10,000 inhabitants, by state. Brazil, 2020.

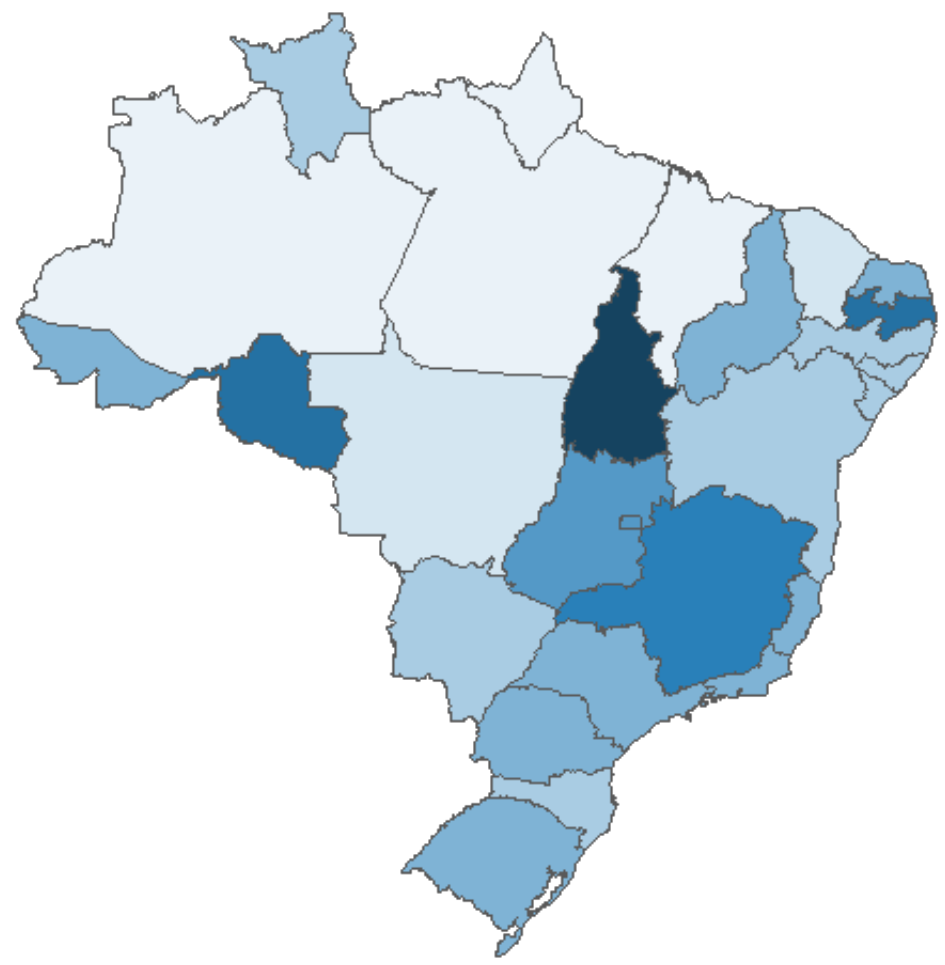

Vacancies per 10,000 inhab.

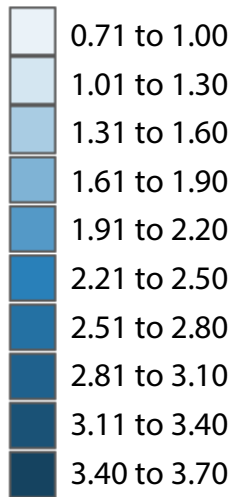

An approximation between the proportions of the regions after the PMM can be observed, which returned to slightly greater differences in 2020. All regions showed a proportion $>1$ vacancy per 10,000 inhabitants, which was true only for the Southeast region up to $2012^{1}$.
Figure 3 shows the relative density of vacancies in medical courses per 10,000 inhabitants in the Brazilian states.

It is possible to observe that the relative density of vacancies per 10,000 inhabitants is unequal between Brazilian regions and mainly between some states, as well as the location 
of courses in the national territory. The lowest relative densities are located in the North. The state of Rondônia, which has the highest relative density within this region, has a small population, less than two million citizens, justifying such density. The Midwest region has 1.8 doctors per 1,000 inhabitants, the second largest ratio among the regions. The fact that the state of Tocantins has the highest relative density of vacancies in the country contributes to these data. The Northeast region has states with different realities, as Maranhão and Ceará have lower relative densities, which are similar to Northern states. Paraíba, on the other hand, has a similar density to Minas Gerais, which are the states with the highest relative densities in their respective regions. The remaining states in the Southeast and South regions have intermediate densities, justified by their larger populations.

\section{DISCUSSION}

This study presents data on medical courses and vacancies, subdivided into public or private schools and tuitionfree or paid schools. This is because the discussion only about the number of medical schools is insufficient to understand the actual distribution in the country. The existence of municipal public administration courses that charge tuition fees means that the categorization into public or private schools, used in most studies in the area ${ }^{4,6,7}$, needs to be more detailed, thus justifying the importance of the category "tuition-free or paid".

A 2015 study that evaluates the implementation of the PMM, one of the main factors that influenced the most recent changes in the number of medical courses and vacancies, pointed out that the process of shifting the location of medical schools towards the countryside had enough power to invert the absolute number of vacancies in the capitals and in the countryside ${ }^{4}$. However, in 2018, Oliveira et. al. showed that the capitals concentrated $30.3 \%$ of vacancies in medical schools, whereas the metropolitan regions (excluding the capital) concentrated $20.7 \%$ of vacancies and the other $49 \%$ were located in the countryside, thus demonstrating that this investment depended on the inclusion of municipalities of metropolitan regions, while countryside towns ${ }^{6}$.

In addition to the capital/countryside classification, this study also evaluated the distance from the municipalities with medical schools to the capital of the respective state. The first calls of the PMM were directed exclusively to cities that were not capitals, had no medical school and were at least $70 \mathrm{~km}$ from a municipality with a medical school ${ }^{4}$. Even so, one can observe a trend towards shifting to the countryside in municipalities closer to the capital, since medical courses located between 1-100 km from the capitals, many of them located in the metropolitan regions themselves, have the highest concentration of vacancies in the countryside, currently reaching $27.8 \%$ of them. It is within this distance interval that the highest concentration of paid medical courses is found, reaching the proportion of $92.8 \%$ of the total vacancies located between $1-100 \mathrm{~km}$ from the capital.

The interval with the highest proportion of public medical schools is $201-300 \mathrm{~km}$ away from the capital, where $48.9 \%$ of the vacancies can be found. Therefore, it is demonstrated that there is a tendency for public medical schools to have to have this shift towards the countryside, which reaches more distant municipalities and contributes to alleviate the inequality in the distribution of medical schools ${ }^{1}$.

The PMM planned for the expansion of the offer of undergraduate medical courses to occur preferably from the increase in the number of vacancies and courses in public universities ${ }^{4,6,13}$, leaving to the private sector the responsibility of opening vacancies that public institutions were not able to create ${ }^{1}$. Moreover, the opening of courses should be carried out in regions with a lower doctor-to-inhabitant ratio, with the goal of providing 2.7 doctors for every 1,000 inhabitants in 2026,

However, vacancies in medical schools have been predominantly offered by private institutions since 1963 and have been progressively increasing ${ }^{6}$, currently reaching $69.2 \%$ of the total ${ }^{7}$. Between 2013 and 2015 there was a considerable public expansion, when there was a greater shift towards the countryside. Even so, most of the vacancies created in that period were in private institutions ${ }^{13}$.

This may have occurred due to the several amendments to the Provisional Measure (PM), later converted into Law $12.871 / 2013$, which changed some criteria for the opening of medical courses. When analyzing these amendments, it can be observed that the significant changes that occurred in the normative acts show the existence of several interests involved in the process of opening medical schools in Brazil, causing both the improvement and the deviation from the initial objectives of the program ${ }^{14}$.

The privatization of undergraduate medicine is also part of the scenario of the expansion of the private education market, benefited by government incentives, such as the Higher Education Student Financing Fund (FIES, Fundo de Financiamento ao Estudante de Ensino Superior) and the 'University for All' Program (ProUni, Programa Universidade para Todos), and through the action of foreign capital and education conglomerates ${ }^{6,15}$. However, when adding the students who obtained a vacancy through these programs, the total does not exceed $20 \%$ of those entering private courses ${ }^{7}$.

Moreover, studies are needed to better understand how access to medical education and the fixation of doctors are correlated. This is because it was observed that students 
from private schools are more likely to leave the state after they graduate than those from public universities ${ }^{6}$. It is important to understand, therefore, that it is not enough to increase the number of students in medical courses in the regions considered to be strategic. Public policies are also needed that favor the fixation of these professionals in these regions, as well as encourage doctors to work in the Unified Health System (SUS) 2,7,16. A study of Medical Demography of 2018 draws attention to the fact that four out of ten newly graduated physicians intend to practice their profession in the city where they were born, with this being the main fixation factor found in such study ${ }^{17}$. Therefore, reserving vacancies or giving advantages in selective processes for students who have finished high school in areas close to the campuses can influence their subsequent fixation at the place where they attended undergraduate school ${ }^{18}$.

The PMM believed that the training of these new professionals would be the main strategy to increase the supply of doctors in Brazil ${ }^{4}$. However, it is worth mentioning that there is no validated parameter in the literature that indicates an ideal number of doctors per 1,000 inhabitants. This ratio depends mainly on the health care model used by each country; in the case of Brazil, we have a public and universal health system, with care coordination based on primary care ${ }^{2}$.

When analyzing international experiences, the Organization for Economic Cooperation and Development (OECD) observed that since 2000, most member countries have experienced an increase in the ratio of doctors/ inhabitants through government initiatives ${ }^{19}$. The number of undergraduate vacancies was increased, because there was some concern regarding the probable shortage of professionals in the future. Some countries also have difficulty in offering an equal distribution of health services between urbanized and central areas and those in the countryside ${ }^{20}$.

In these countries, it was observed that just by increasing the number of doctors was not effective in solving such a disparity, with the need for measures such as those reported by Strasser in Canada, who chose the opening of medical schools in countryside areas. South African studies ${ }^{21}$ suggest that the countries that had the most success in better distributing their professionals have used five main strategies: pre-selection of students who are interested in pursuing a career in the countryside; curricular readjustment promoting the interest of activities in rural areas; government imposition that moves health professionals to rural areas; financial incentives for professionals working in the countryside and creation of support structures that help professionals from non-central regions ${ }^{21}$.

Another indicator used by the PMM to assess the distribution of courses in Brazil was the number of vacancies per 10,000 inhabitants ${ }^{8}$. When observing the data for 2012, the year before the program started, it is possible to identify that the Midwest, Northeast and North regions had the lowest vacancy rates per inhabitant ${ }^{1,4}$. There was a poor distribution of vacancies among the different regions, such as the Northeast, which, even though had the second largest population in the country ${ }^{22}$, was the second region with the lowest vacancy rate per 10,000 inhabitants 4 .

During the period from 2013 to 2015, the Midwest and Northeast regions showed the greatest increase in vacancies, of $58 \%$ and $48 \%$ respectively, followed by the South region with $28 \%$, North with $24 \%$ and Southeast region with $17 \%{ }^{4}$, which justifies the better balance regarding the distribution of vacancies by region observed after the program implementation ${ }^{4}$.

It is also worth discussing the contradiction found in the PMM, which although supports a model focused on primary health care, it concentrates its efforts on opening new vacancies and the creation of new courses for one type of health professional only, the physician. ${ }^{2}$ When taking actions based only on indicators about the availability of these professionals, the PMM affects the different aspects of the integrality of health, and therefore there is the risk, even after so much investment, of being insufficient for part of the population's health needs. This is because Article n.1 of Law 12.871 clarifies the purpose of training human resources in the medical field, not aiming at opening undergraduate courses for other professions in the health field ${ }^{3}$. It should be noted that this research did not seek information on the opening of these other courses, which may have been influenced by the opening of medical schools, even though it was not a direct objective of the PMM.

To analyze the distribution of courses and vacancies in relation to the $\mathrm{HDI}$ of the municipalities, it is necessary to understand that the HDI is calculated from three indicators of a given region: long and healthy life, access to knowledge and the right to a decent standard of living. However, more than education, longevity and income, the HDI indicates conditions in which the prosperity of the group of individuals living in the analyzed location will be more or less likely ${ }^{9,23}$.

A low HDI indicates that individuals survive amid diverse conditions of oppression and misery. Such a situation creates obstacles for "the development of the human being towards oneself" and, moreover, "choices are simply not available, and many life opportunities remain inaccessible"23.

Currently, there is no active medical schools in Brazil in cities with a low HDI. The Brazilian HDI at the time of the last calculation, in 2010, was average $(0.699)^{24}$. However, most medical schools are located in places with high or very high $\mathrm{HDI}$. This can be due to several factors, among them the fact 
that most vacancies for undergraduate medical school in Brazil are in paid schools. Two institutions charge less than $R \$ 5,000$ reais per month, among the 218 that have paid courses ${ }^{25}$, and such monthly fees are very distant from the average monthly income, per capita, of Brazilians, which is $\mathrm{R} \$ 1,439$. Even when considering the richest $10 \%$ of Brazilian citizens, who have an average income of $R \$ 5,214$, the cost of the school would compromise almost $100 \%$ of the income ${ }^{24}$.

Moreover, cities where more income circulates tend to have more of the necessary preconditions, according to the MEC proclamations, for the opening of medical schools, such as the existence of Multiprofessional Home Care Teams, the existence of urgency and emergency beds or Emergency Room and Medical Residency Programs in priority specialties ${ }^{26}$. As a consequence, there is a strong impact on the access to medical courses by students from the economically less favored social strata ${ }^{7,17}$.

A predominantly private expansion process and in regions that concentrate much of the country's income, raises questions about medical training that does not meet the social needs of the democratization of access to higher education ${ }^{15}$. Therefore, the relevance of having government regulation involved in the creation of new schools is reinforced, due to the impacts of this process of education commercialization ${ }^{13}$.

As this is a cross-sectional study, this study is not able to analyze the moment when each vacancy was created. It should also be noted that the analyses presented herein refer to the number of vacancies for the first-year medical students, since the total number of medical students can be influenced by changes each year, in addition to other aspects such as the course dropout rates. Furthermore, the e-MEC system is just one of the data sources that have such information, and it is important to compare the number of vacancies found with the number offered through the College entrance exams of each institution or even in national selection processes, such as PROUNI.

\section{CONCLUSIONS}

Medical education is under several influences: macrostructures, economic and political trends, the definition of what health is and what health needs are, the ways in which medical practice, services, health policies and society as a whole are organized2. The discussion regarding the offer of medical courses needs to take these facts into account, in addition to also addressing the aspects that were listed throughout this study, such as regionalization, the democratization of access, the qualification of the care network and the responsibility for the construction of the health system.

It is possible to conclude that there was a greater shifting of medical courses to the countryside, since there are more courses in the countryside of the states, although most of them are located in municipalities that are closer to their respective capitals. Moreover, it was observed that public medical schools tend to be located in municipalities that are more distant from the capital, different from the private courses.

There was a better distribution of vacancies across the country, with an increase in the regions need medical courses the most, such as the North and Northeast regions. However, the concentration of vacancies still predominates in the Southeast region, which has approximately half of the total number of vacancies. All Brazilian regions have already surpassed the mark of one vacancy in a medical course for every 10,000 inhabitants.

It can be said that municipalities with higher HDI ranges have a higher proportion of paid medical courses. The maintenance of the strong privatization process with the increase in the number of vacancies in private courses raises the question about which profile of students will have access to medical education. Thus, the concern regarding greater "flexibility" in the private expansion in existing courses ${ }^{4}$ is a legitimate one.

In 2018, the 323 active medical schools offered a total of 32,626 undergraduate vacancies for new students6. Now in 2020, the 328 ongoing medical courses offered 35,480 vacancies. Knowing that the largest offer of a single course is 342 vacancies for first-year students 8 , it is possible to conclude that the five courses started during this period are not the only ones accountable for the 2,854 new vacancies.

Therefore, it is necessary that entities historically involved in this debate, such as the Brazilian Association of Medical Education and the National Executive Board of Medical Students, in addition to medical schools, managers, teachers and students, remain alert in relation to the decisions of government bodies. They must also remain focused, aiming to build initiatives that qualify medical education and are committed to the consolidation of SUS, according to the health needs of the Brazilian population.

\section{ACKNOWLEDGMENTS}

To ABEM Board of Directors for their support, from the study conception to the writing of the manuscript. To the FCMMG statistical team for their availability and study review.

\section{AUTHOR'S CONTRIBUTION}

All authors contributed equally to the development of the article.

\section{CONFLICTS OF INTEREST}

The authors declare no conflict of interests.

\section{SOURCES OF FUNDING}

The authors declare no external sources of funding. 


\section{REFERENCES}

1. Brasil. Programa Mais Médicos - dois anos: mais saúde para os brasileiros. Brasília: Ministério da Saúde, Secretaria de Gestão do Trabalho e da Educação na Saúde; 2015.

2. Matias MC, Verdi M, Finkler M, Ros MAD. O Programa Mais Médicos no contexto das estratégias de mudança da formação médica no país: reflexões e perspectivas. Saúde Soc. 2019;28:115-27 [acesso em $10 \mathrm{fev}$ 2020]. Disponível em: https://www.scielosp.org/article/sausoc/2019. v28n3/115-127/pt/.

3. Oliveira FPD, Pinto HA, Figueiredo AMD, Cyrino EG, Oliveira Neto AVD, Rocha VXMD. Programa Mais Médicos: avaliando a implantação do Eixo Formação de 2013 a 2015. Interface (Botucatu). 2019;23:e170949 [acesso em 7 abr 2020]. Disponível em: http://www.scielo.br/scielo. php?script=sci_arttext\&pid=S1414-32832019000600203\&lng=pt\&nrm= iso.

4. Lampert JB. Dois séculos de escolas médicas no Brasil e a avaliação do ensino médico no panorama atual e perspectivas. Gazeta Médica da Bahia. 2008;78(1):31-7 [acesso em 7 abr 2020]. Disponível em: http://www. gmbahia.ufba.br/index.php/gmbahia/article/viewFile/255/246.

5. Oliveira BLCAD, Lima SF, Pereira MUL, Pereira Júnior GA. Evolução, distribuição e expansão dos cursos de medicina no Brasil (18082018). Trab Educ Saúde. 2019;17(1):e0018317 [acesso em $07 \mathrm{abr}$ 2020]. Disponível em: http://www.scielo.br/scielo.php?script=sci_ arttext\&pid=S198177462019000100509\&lng=pt\&nrm=iso.

6. Brasil. Lei $n^{\circ} 12.871$, de 22 de outubro de 2013. Institui o Programa Mais Médicos, altera as Leis n 8.745, de 9 de dezembro de 1993, e n 6.932, de 7 de julho de 1981, e dá outras providências. Diário Oficial da União; 23 out 2013 [acesso em 6 abr 2020]. Disponível em: http://www.planalto.gov.br/ ccivil_03/_Ato2011-2014/2013/Lei/L12871.htm.

7. Martins MA, Silveira PSP, Silvestre D. Estudantes de medicina e médicos no Brasil: números atuais e projeções. Projeto avaliação das escolas médicas brasileiras: relatório I. São Paulo: Programa de Apoio Institucional ao Desenvolvimento do Sistema Único de Saúde; 2013 [acesso em 7 abr 2020]. Disponível em: http://www.fm.usp.br/cedem/conteudo/ publicacoes/cedem_92_relatoriopaemi.pdf.

8. Ministério da Educação. Instituições de educação superior e cursos cadastrados. Brasília: e-MEC; 2020 [acesso em 27 fev 2020]. Disponível em: http://emec.mec.gov.br/.

9. Instituto Brasileiro de Geografia e Estatística. IBGE cidades [acesso em 27 fev 2020]. Disponível em: https://cidades.ibge.gov.br

10. Instituto Brasileiro de Geografia e Estatística. Estimativas da população residente no Brasil e unidades da Federação com data de referência em $1^{\circ}$ de julho de 2019. Brasília: IBGE; 2019 [acesso em 7 jun 2020]. Disponível em: ftp://ftp.ibge.gov.br/Estimativas_de_Populacao/Estimativas_2019/ estimativa_dou_2019.pdf

11. Peres RG, Zimmermann G. Gestão e planejamento de cidades e políticas sociais: gestão metropolitana - possibilidades e desafios. In: Baeninger $\mathrm{R}$, organizadora. População e cidades: subsídios para o planejamento e para as políticas sociais. Campinas: Núcleo de Estudos de População (Nepo)/Unicamp; 2013. p. 210-12 [acesso em 14 abr 2020]. Disponível em: http://www.nepo.unicamp.br/publicacoes/livros/pop_e_cidades/ pop_e_cidades.pdf.

12. Programa das Nações Unidas para o desenvolvimento [Internet]. Brasília: PNUD ONU; 2013 [acesso em 4 mar 2020]. Disponível em: https://www.br.undp.org/content/brazil/pt/home/idh0/rankings/idhmmunicipios-2010.html.
13. Oliveira FPD. As mudanças na formação médica introduzidas pelo Programa Mais Médicos [tese]. Brasília: Universidade de Brasília; 2018 [acesso em 10 mar 2020]. Disponível em: https://repositorio.unb.br/ handle/10482/34447.

14. Oliveira FPD, Costa AM, Cardoso AJC, Trindade JDS, Dias IMAV. Análise das emendas parlamentares ao Programa Mais Médicos: o modelo de formação médica em disputa. Saúde Debate 2017;41:60-73 [acesso em 3 jun 2020]. Disponível em: https://www.scielosp.org/article/sdeb/2017. v41nspe3/60-73/.

15. Scheffer MC, Dal Poz MR. The privatization of medical education in Brazil: trends and challenges. Hum Resour Health. 2015;13(1):96 [acesso em 27 fev 2020]. Disponível em: https://human-resources-health.biomedcentral. com/articles/10.1186/s12960-015-0095-2.

16. Figueiredo AM, McKinley DW, Lima KC, Azevedo GD. Medical school expansion policies: educational access and physician distribution. Med Educ. 2019;53(11):1121-31 [acesso em 24 maio 2020]. Disponível em: https://onlinelibrary.wiley.com/doi/epdf/10.1111/medu.13941.

17. Scheffer M, Cassenote A, Guilloux AGA, Biancarelli A, Miotto BA, Mainardi GM. Demografia médica no Brasil 2018. São Paulo: FMUSP, CFM, Cremesp; 2018 [acesso em 28 abr 2020]. Disponível em: http://www.flip3d.com.br/ $\mathrm{web} / \mathrm{pub} / \mathrm{cfm} /$ index $10 /$ ?numero $=15 \&$ edicao $=4278$.

18. Germano, JCV. Perfil dos estudantes do Curso de Medicina da Escola Multicampi de Ciências Médicas do Rio Grande do Norte/UFRN [dissertação]. Natal: Universidade Federal do Rio Grande do Norte; 2017 [acesso em 16 set 2020]. Disponível em: https://repositorio.ufrn.br/jspui/ handle/123456789/25036.

19. Organization for Economic Cooperation and Development. Health at a Glance 2015: OECD Indicators. Paris: OECD; 2016 [acesso em 16 set 2020]. Disponível em: http://dx.doi.org/10.1787/health_glance-2015-en.

20. Strasser RP, Lanphear JH, McCready WG, Topps MH, Hunt DD, Matte MC. The Northern Ontario School of Medicine: Social Accountability Through Distributed Community Engaged Learning. Canada: Academic Medicine; 2009 [acesso em 16 set 2020]. Disponível em: https:// journals.Iww.com/academicmedicine/fulltext/2009/10000/canada_s_ new_medical_school_the_northern_ontario.39.aspx?casa_token $=\mathrm{b}$ T82UIP3_hwAAAAA:gfhYMu5SPx9q7so4jSJvbfVvrnSy12MJve28qhG7Pqw8eivtxU_ynhCl5clTFrX7bd1xzikHfpyfY3nlrbBsWBiF.

21. Wilson NW, Couper ID, Vries ED, Reid S, Fish T, Marais B. A critical review of interventions to redress the inequitable distribution of healthcare professionals to rural and remote areas. Rural Remote Health. 2009;9:1060 [acesso em 16 set 2020]. Disponível em: https://www.rrh.org.au/journal/article/1060.

22. Instituto Brasileiro de Geografia e Estatística. População residente enviada ao Tribunal de Contas da União: Brasil, grandes regiões e unidades da Federação - 2001-2014. Brasília: IBGE; 2013 [acesso em 7 jun 2020]. Disponível em: tp://ftp.ibge.gov.br/Estimativas_de_Populacao/Estimativas_2014/serie_2001_2014_TCU.Pdf.

23. Bitoun J. O que revelam os índices de desenvolvimento humano. Prefeitura et al. Recife, PE, 2005 [acesso em 24 mar 2020]. Disponível em: www.recife. pe.gov.br/pr/secplanejamento/pnud2006/doc/analiticos/O\%20que\%20 revelam $\% 20$ os $\% 20 \%$ C3\%8Dndices $\% 20$ de $\% 20$ Desenvolvimento $\% 20$ Humano\%20(IDH).pdf.

24. Nassif ACN. Escolas Médicas do Brasil [Internet] Brasil: Antônio Celso Nunes Nassif [acesso em 27 fev 2020]. Disponível em: www.escolasmedicas.com.br.

25. Ministério da Educação. Edital n 6, de 22 de dezembro de 2014. Primeiro edital de chamada pública de mantenedoras de instituições de educação superior. Diário Oficial da União; 23 dez 2014. 